\title{
The Impact of Hallyu 4.0 and Social Media on Korean Products Purchase Decision of Generation C in Vietnam*
}

\author{
Nguyen Xuan Truong ${ }^{1}$
}

Received: May 30, 2018 Revised: July 18, 2018 Accepted: July 30, 2018

\begin{abstract}
This study developed and tested the impact of hallyu 4.0, social media, and consumer ethnocentrism on the decision to purchase Korean products of Generation C in Vietnam. Both qualitative and quantitative methodologies were utilized in this study. Qualitative research was first carried out with in-depth interview, conducted to derive measurement items for the interested constructs. Quantitative research used cross-sectional field design by pilot study and official study. The model was tested and developed using data collected by questionnaires, from a sample of 575 respondents, by both electronic and paper surveys with non-probability and convenience sampling techniques. SPSS 20 and AMOS 20 software were employed to analyze the data. The results of structural equation modeling showed that hallyu 4.0, social media, and consumer ethnocentrism influenced the intermediates variables: subject norms, trust, attitude and behavioral intention and influenced purchase decision. The hallyu 4.0, social media, and consumer ethnocentrism are independent variables. They impact purchase decision through mediating variables such as trust, subjective norms, attitude and behavioral intention. Social media influences not only to trust but also to subjective norms. Subjective norms influence on purchase decision. This study also discovers an interesting fact that trust and attitude variables have an impact on behavioral intention and purchase decision.
\end{abstract}

Keywords: Hallyu 4.0, Social Media, Korean Product, Generation C, Vietnam.

JEL Classification Code: M31, M37, M39.

\section{Introduction}

Generation C are connected, members of this generation have a tight connection with other people and things in the way people never had in the past. Specifically, they employ online channels to create content, post statuses or pictures, watch videos and exchange knowledge, etc. In terms of

* The paper was presented initially at 2018 International Conference on Business and Economics (ICBE2018) and the 14th International Conference of KODISA that was held in Seoul, South Korea, June 25-27, 2018. The paper has been recognized as one of Best Paper Awards at ICBE2018 conference. This paper is a substantially revised and expanded version of the paper presented at ICBE2018 conference. The authors have taken into account all the comments of Editors, Session Chairs and Reviewers in the revised manuscript. The authors greatly appreciate Editors, Session Chairs and Reviewers for their valuable comments, interest in and support of this research.

1 First Author and Corresponding Author. Professor and Dean, Faculty of Marketing, University of Finance - Marketing, Ho Chi Minh City, Vietnam [Postal Address: 105/1 Binh Quoi Street, Ward 27, Binh Thanh District, Ho Chi Minh City, 700000, Vietnam] Email: ts.truong@gmail.com generation $C$, researchers are having trouble pinpointing the main characteristics of this category and who should be included in this group. Some researchers used the year when a person was born to answer this question. Pikett (2017) showed research results of CEFRIO, a public-private technology transfer group in Quebec, Canada, defining generation $C$ as a group of individuals born between the year of 1982 and 1996. This would actually place generation $C$ within the group of generation $Y$ or millennials. Others referred to generation $\mathrm{C}$ as a "psychographic" group, or a number of individuals who shared similar opinions and states of mind, whether that were certain personality traits, values, attitudes, interests, or lifestyles.

According to Booz \& Company (2010), generation C was connected, communicating, content-centric, computerized, community-oriented, and always clicking. They were born after 1990 and lived their adolescent years after 2000. In this study, generation $C$ is referred to as those who were born between 1990 to 2000. Besides, Korean new cultural trend also had a significant impact on the exports of Korean product and increased tourism (Lee, 2015; Hogarth, 2013). According to Kim (2015), hallyu (Korean wave) 1.0 emerged with K-drama exports in the late 1990s, then came hallyu 
2.0 with $\mathrm{K}$-music, hallyu 3.0 with $\mathrm{K}$-culture, and hallyu 4.0 with K-style. Hallyu had then increased the purchase of Korean-related products by foreign customers ( $\mathrm{Yu}$ et al., 2012). The Internet and social media are growing fast globally and in Vietnam for the past 5 years. Overall, Vietnam had got over 64 million internet users $(48,1 \%$ population) as of December 31, 2017 (Internetwordstats, 2018) and 58 million Facebook users as of April 2018 (Statista, 2018). Hallyu 4.0 (K-style) had increased the purchase of Korean-related products among Vietnamese customers. Nowadays, generation $C$ in Vietnam is influenced by hallyu 4.0 and social media and they usually search for information, prospective reviews from other people through social networking sites.

Despite the influence of hallyu 4.0 and social media to purchase decision of generation $C$ has not been interested in researching and applying in business. In this study, conceptual model was developed, including hallyu 4.0, social media, consumer ethnocentrism, subjective norms, trust, and attitude constructs resulted from previous studies, in order to explain an individual's intention and the purchase decision of Generation C in Vietnam.

\section{Literature Review, Hypotheses Development and Conceptual Model}

\subsection{Social Media (SM)}

Social media is an e-space for social activism and support, emotional expression, news updating, as well as friendship developing. It is a means for people to share their photos, post statuses, update their daily lives and communicate with other people, which derive a sense of self-assurance and belonging. Social media has been powerful in changing the way people connect with one another, and has brought many positive outcomes. In addition, when it comes to purchasing goods, users of social media can collect information from the huge online database to make their own decision. Social media independent variables played an important role in affecting purchase decision and its usage also impacted purchase decision (Mathupur, Black, Cao, Berger, \& Weinberg, 2012). Furthermore, Mangold and Faulds (2009) stated that social media had influenced consumer journey from information acquisition to post purchase such as dissatisfaction statements and behaviors.

According to Cruz and Mendelsohn (2010), consumers who were fans of a brand on social media were more likely to recommend or buy from that brand. Specifically, consumers trust leaned toward their fellows' information rather than the one created by organizations (Nielsen, 2009).
In contrast, millennials had an opposing idea when $51 \%$ of them stated that consumer opinions found on a company's website had a greater impact. Besides, there has been one problem with social media, which is an ambiguity concerning what behavior is appropriate online. It happens when a recognized set of norms have not caught up with the speed in which social media has been adopted into our lives. The unique features, platform enforcement together with the nature of social media have created an environment in which healthy subjective norms are not ubiquitously followed. This study was also conducted to understand the influence of social media on not only subjective norms but also trust. Hence, I would expect hypotheses that:

$\mathrm{H} 1$ : social media has a positive influence on subjective norms.

H2: social media has a positive influence on trust.

\subsection{Hallyu 4.0 (HA)}

The term "hallyu" or Korean wave first emerged in Taiwan and was referred to Korean companies and/or products in 1997 by The China Times. Hallyu and Korean wave are interchangeable as they both share the same meaning. Hallyu was introduced with the film Jealousy shown in Fukuoka, Japan in 1993, opening a new era of Korea's conquest of Asian entertainment industry. Hallyu is a Korean cultural production trend that comprises of all Korearelated fields such as music, film, foods, sports, and tourism. According to Lee (2011), hallyu was the forefront of Korean dramas and Korean pop as these two popular cultural products were a catalyst to further promote other Korean cultural products. Although the "Korean wave" term consisted of both K-dramas and K-pop, K-pop resonated specifically well with Asian teenagers for creating a unique blend of Asian and Western sensibilities.

According to $\mathrm{Kim} \mathrm{(2015),} \mathrm{hallyu} 4.0$ is K-style. Vietnamese's generation $C$ has been blown away by the new wind of hallyu which inspires them to become younger, more dynamic, more active in the mainstream pop culture. The positive impacts of hallyu are associated in the field of perception and hallyu indirectly influences attitude. Lee (2007) and Kim and Park (2004) found the positive and significant relationship between hallyu and the attitude toward Korean products. The research result of $\mathrm{Yu}$ et al. (2012) showed that products relating to Korean culture such as tourism, contents, cosmetic products could be influenced. Many researchers also proved that hallyu had positive effects on the exports of Korean products and increased tourism (Pang \& Hwang, 2007). This study was then conducted to understand the influence of social media to perception. There was, thus, hypothesis: 


\section{H3: Hallyu 4.0 has a positive influence on trust.}

\subsection{Consumer Ethnocentrism (CE)}

The term "consumer ethnocentrism" was first introduced by William (1906), a sociologist and researcher on the position of consumers on the rise which became very important in the process of globalization. Position of consumers is the result of their interest and love for the country along with their fear of adverse consequences, since imports rate can cause serious problems for local economic development method. Baughn and Yaprak (1996) stated that the intention and buying decision was treated as a reward while enjoying a psychological goal and a sense of achievements to avoid contact with other cultures and countries. The purchase of foreign products may lead to the involvement of high feelings especially when it comes to national security or job loss. Position of consumer strains had a negative and direct impact on intentions to purchase a foreign product (Shimp \& Sharma, 1987).

Herche (1992) found that consumer strain tastes could be used to predict preferences to buy goods produced in the country instead of abroad. Shoham and Brenečić (2003) also reported that position of consumer strains had a significant impact on consumer's buying decision. Highest strain taste leads to detrimental attitudes with lower intention to buy foreign products. Many other studies had examined the impact of the position of consumers on purchase behavior tendencies; however, there were different results depending on characteristics of consumers and their country (Nguyen et al., 2008; Ranjbairn et al., 2011). Some studies by Ramaswamy et al. (2000), Balabanis and Diamantopoulos (2004), and Nguyen (2016) in developing countries had confirmed the existence of negative trend of consumer taste for foreign product purchase behavior. Thus, the hypotheses set out:

\section{H4: consumer ethnocentrism negatively impacts trust. \\ $\mathrm{H} 5$ : consumer ethnocentrism negatively influences purchasing decisions.}

\subsection{Subjective Norms (SN)}

According to Ajzen (1991) and Fishbein and Ajzen (2010), subjective norms were the social determinants of intention and the reflection of social pressure perception on a given behavior. Subjective norms concerned the perceived social pressures to undertake or not undertake a particular behavior (Ajzen, 1991; Giffrin et al., 2007). They referred to an individual's perceptions of whether other people who were important to them think that they should or should not perform one behavior (Ajzen \& Fishbein, 1980). The concept of social influence assessed by social norms and normative belief was presented in both the theory of reasoned action and the theory of planned behavior. The theory of planned behavior specified the nature of relationships between beliefs and attitudes.

According to Ajzen and Fishbein (1975), people's evaluations of, or their attitudes toward a behavior were determined by their accessible beliefs about the behavior, where a belief was defined as the subjective probability that a certain outcome would happen as a result of the behavior. According to the theory of reasoned action, if people evaluated the suggested attitude as positive, and if they thought that their significant others wanted them to perform the behavior (subjective norms), this resulted in a higher intention (motivations) and they would be more likely to undertake that behavior. Many studies have shown a high correlation of subjective norms and attitudes to behavioral intention, and subsequently to behavior (Sheppard, Hartwick \& Warshaw, 1988). From some definitions above, it can be summarized that subjective norms in general is an individual's set of perceptions of whether they should or should not do the behavior, taking social pressure and opinions of their important persons into consideration. Not only do subjective norms affect attitude, they also directly impact decision-making stage. Therefore, the specific hypotheses to be tested were:

H6: subjective norms positively impact attitude.

$\mathrm{H} 7$ : social norms positively impact purchase decision.

\subsection{Trust (TR)}

Trust has been defined in different ways in the literature. Trust played an important role in forming and maintaining long-term relationships (Sanchez Iniesta, Schlesinger, \& Rivera, 2010). According to Cho (2007), trust referred to the confidence a person has in his or her favorable expectations of what other people would do. Rousseau, Sim, Ronald and Colin (1998) debated that trust was defined as a psychological state comprising the intention to accept vulnerability based on positive expectations of intentions or behavior of another. In addition, trust had also been seen as a set of specific, including ability, benevolence, integrity, and predictability (Gefen, 2002). Gefen, Karahanna and Straub (2003) showed that the people relied on trust in order to reduce social ambiguity. The importance of trust has also been cited in e-commerce. Social media network users often expressed their thoughts, beliefs and choices and showed trust in safety within the circle of netizens (Shin, 2010; Pitta \& Fowler, 2005). 
According to a survey of US internet-using mom by an online video reviewing site expo, consumer reviews gained nearly 12 times more trust than descriptions of manufactures. Some results of study showed that trust had a great impact on consumers buying behavior. According to Smiciklas (2011), trust was important factor leading to a positive impact. The force that urges customers to share positive stories or messages about a certain brand or product is the trust they enjoy with that brand or product, and the trust between them and people they talk to. In accordance to Bazaavoice (2012), over half of millennials (consumers aged 18 to 34 ) trusted the opinions of strangers online over those of friends and family. Online trust would also function as the facilitator for formulating positive purchase intention and further purchase decisions. Yoon (2002) stated that both online and offline trust had had a great impact on the consumer's purchase decision. Trust strongly affected specific behavioral intentions and trust had a strong influence on three key consumer intentions (Harrison, Vivek, \& Charles, 2002; Nguyen, 2015). This study set out the hypothesis:

H8: Trust has a positive influence on attitude toward behavior.

\subsection{Attitude Toward Behavior (AT)}

Attitude describes the reviews, thoughts, relatively consistent tendencies of humans against an object or an idea. Attitude puts humans into the framework to think about things they like or don't like. The theory of reasoned action (TRA) and theory of planned behavior (TPB) were developed focusing on trust and attitudes as determinants of consumer buying behavior. According to Ahtola (1975) and Loudon and Della Bitta (1993), both TRA and TPB proposed that a person's overall attitude toward an object was derived from his or her beliefs and feelings about various attributes of that object. The relative contributions of attitudes and subjective norms would not necessarily be equal in predicting behavior. In the TPB, behavioral intention was controlled by a dynamic mix of the attitude and subjective norm.

According to Ajzen (2006), actual behavior was again derived largely from behavioral intention, but was mediated to some degrees by perceived behavioral control. In the TRA, attitude toward the buying behavior is measured rather than simply the attitude toward the object. Consumers often buy when they trust and have a positive attitude to a seller, the product or service. The attitude has a long-term trend based on the values and beliefs of the people and are difficult to change. Attitudes affect buying intentions, thus posing the hypothesis:
H9: Attitudes positively influence behavioral intention.

\subsection{Behavioral Intention (BI)}

Intention refers to the willingness for a purchase decision. It has a positive influence on the purchase decision. According to Zeithaml, Berry and Parasuraman (1996), BI were indicators that customers will stay or leave the companies. Research following TRA and technical acceptance models (TAM) by Bernadette (1986) showed a high correlation between intentions and actual use. Ajzen and Fishbein (1980) and Featherman and Pavlou (2002) described the positive relationship between $\mathrm{BI}$ and action. The study conducted by Sommer (2011) showed that BI referred to an individual motivation and conscious plan to expand effort and perform a behavior. In addition, research studies by Zeng, Hu, Chen and Yang (2009), Brady and Robertson (2001), and Jackson et al. (1997) revealed that service quality and consumer satisfaction affected $\mathrm{BI}$ and indicated that $\mathrm{BI}$ could be favorable and unfavorable as well. Therefore, the following hypothesis was examined:

H10: behavioral intention positively influences purchase decision.

\subsection{Purchase Decision (PD)}

Individual factors mostly have control over their behavior, which is voluntary and performed under the individual's free will. However, if there is a strong attitude and intention toward undertaking a particular action, actual behavior will occur. A favorable behavioral intention is more likely to result in repurchase than in the case of an unfavorable intention. According to Davis, Foxall and Pallister (2002), an individual could intend to perform a particular activity but might not realize it due to some outside conditions. A study conducted by Akhter (2010) showed that overall satisfaction had a significantly positive impact on purchase intention, and purchase intention had a significantly positive impact on actual repurchase. When asked which sources of information "influence your decision to use or not to use a particular company, brand or product", $71 \%$ of people surveyed claimed that reviews from family members or friends exerted a "great deal" or "fair amount" of influence on them (Nielsen, 2012). 


\subsection{Conceptual Model}

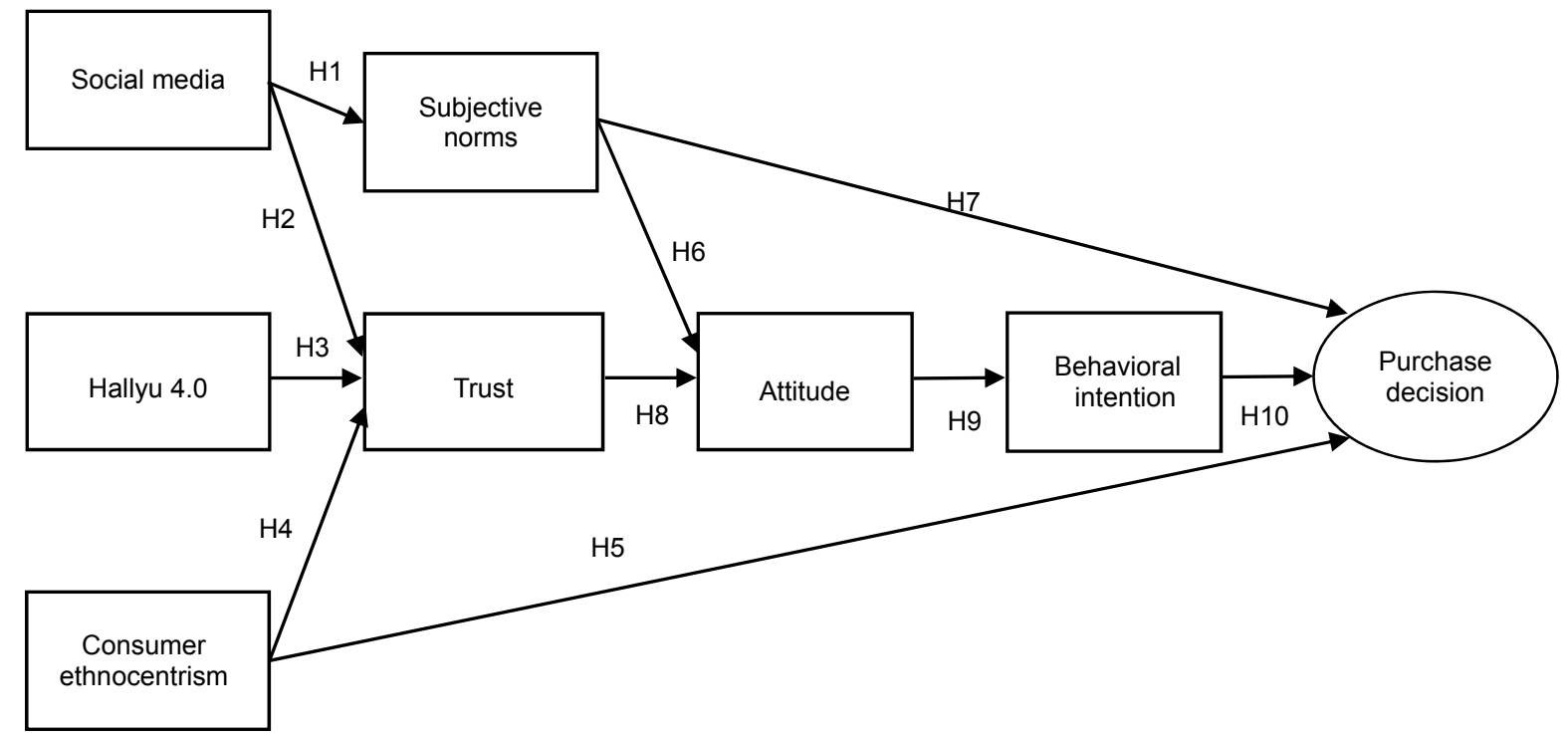

Figure 1: Conceptual model

In order to achieve the study's objectives, the conceptual framework was developed based on the theory of reasoned action (TRA) (Fishbein \& Ajzen, 1975), theory of planned behavior (Ajzen \& Icek, 1991) and the trust model (Mayer, Davis, \& Schoorman, 1995). According to TRA model, a person's actual behavior could be determined by considering their prior intention along with the attitude that person would have for the given behavior. The intention that a person had prior to an actual behavior could be a factor affecting the behavioral intention, and defined it as a measure of one's intention that could be determined by considering both the attitude which a person had toward the actual behavior (Fishbein \& Ajzen, 1975).

The attitude variable eliminated any unexplained direct influence observed from the system characteristics to the attitude variable. This conceptual framework is modified by applying eight variables to find out the impact of hallyu 4.0, social media, social norm, consumer ethnocentrism, trust, attitude on behavioral intention to purchase and purchase decision on Korean products purchase of Generation $\mathrm{C}$ in Vietnam (Figure 1).

\section{Research Methods}

The conceptual model was developed on the basis of the hypotheses needed to be validated empirically using mixed research method. In order to do this, qualitative approach and quantitative approach were applied. Qualitative research was carried out by in-depth interview with 15 participants. The questionnaire consisted of 2 sections of unstructured questions and structural questions. The unstructured questions were used to regulate the question for clarification, made them easy to understand.

The structural questions were used to test face/content validation. A total of 15 responses in the in-depth interview were to analyze each measurement items regarding essentiality and classified them into "not necessary", "useful but non-essential", and "essential" category. For each item, the number of judges categorizing the item as "essential" was computed for calculation of the Content Validity Ratio (CVR). Following Laewshe's (1975), the formula for the content validity ratio (CVR) was devised: CVR $=[\mathrm{Ne}-$ $(\mathrm{N} / 2)] /(\mathrm{N} / 2)$, with: $\mathrm{Ne}$ was the number of participants indicating "essential" and $\mathrm{N}$ was the total number of participants. While the CVR was a direct linear transformation from the percentage saying "essential," its utility derived from its characteristics: When fewer than half said "essential," the CVR was negative. When half said "essential" and half did not, the CVR was zero. To decide the significance of each item, Laewshe's proposal (1975) was used, and a $5 \%$ significance level was adopted.

Quantitative approach was applied by the use of questionnaires. Quantitative approach used cross-sectional field design, as it was the best way to identify relatively strong effects on dependent variables and intermediate variables, enhancing the statistical results. This was a feasible approach for measuring complex variables and 
forming hypotheses. For testing the conceptual model and hypotheses, SPSS 20 and AMOS 20 software were utilized. This study applied non-probability with convenience sampling technical. The study was conducted in three regions of Vietnam: Northern, Central and Southern. A sample size of 575 satisfied the criteria for the statistical validity of the descriptive and SEM statistical techniques (Yurdugul, 2008).

Data was collected using a self-administered questionnaire where the measurement of variables was based on existing measuring instruments. The form of questionnaire in this research applied a 5-point Likert scale ( $1=$ strongly disagree; $5=$ strongly agree). The questionnaire was tested for validity and reliability by in-depth interview and was also done before collecting the data. Questionnaires were distributed both electronically and by paper. The data for this study was obtained by an electronic survey distributed on Facebook, via email, and through face-to-face survey. Administration process took 30 days. After a review of all responses, 592 responses (262 paper \& 330 electronic) were considered proper. After being screened, 575 responses were considered proper and valid for further analysis.

\section{Results}

\subsection{In-depth Interview}

The 8 constructs (variables) with 40 measurement items draft was developed from theoretical basic to test by an indepth interview through face/content validation. The result of the in-depth interview was one measurement item (CE4) was deleted from questionnaire and 39 measurement items was qualified to go through pilot study.

\subsection{Pilot Study}

Pilot study was used to test reliability of measurement items. 115 respondents for measurement items test by pilot study used in reliability analysis showed the homogeneity of questionnaires. Under this conceptual model, the alpha coefficients of the constructs and survey form were as follows. Cronbach's alpha of 8 constructs was more than 0.7 and was acceptable exhibit high degrees of reliability. From 39 measurement items, only 2 measurement items HA5 and TR4 had corrected item-total correlation lower than 0.3 so it was not acceptable and 37 measurement items were acceptable (Nunnally, 1978; Peterson, 1994; Staler, 1995). The 37 measurement items were reliable as shown in questionnaire in official study.

\subsection{Official Study}

\subsubsection{Descriptive Analysis}

This survey collected a total of 592 responses, in which 17 invalid responses were eliminated and 575 responses were retained for analysis. The response rate was, therefore, $97.13 \%$. In the aggregate sample, $46.1 \%$ of respondents were males and $53.7 \%$ were females. $100 \%$ of them belonged to the Generation C, defined as people who were born between 1990 and 2000. 20.5\% of respondents were from the North, $15.1 \%$ from the Central and $64.4 \%$ from the South of Vietnam. Almost $89.0 \%$ of the respondents' education background was college/university level and above.

\subsubsection{Cronbach Alpha Test}

Before exploratory factor analysis (EFA), the measurement items were tested for reliability by Cronbach's alpha coefficients. A higher Cronbach's alpha score indicated greater reliability and its acceptable lower limit was 0.7 (Nunnally \& Bernstein, 1994). In our research, the alpha scores of constructs were between 0.703 to 0.845 . Corrected item-total correlation of TR5 and IB5 were below 0.3 , so they were removed from the conceptual model and 35 measurement items continue to go through exploratory factor analysis.

\subsubsection{Exploratory Factor Analysis}

The measurement items were refined using exploratory factor analysis and poorly fitted items were excluded from the study. The results of the conceptual model, which included the standardized factor loadings, standard errors, construct reliabilities, and proportions of variance extracted for each construct were presented. Factor loadings of the indicators for each construct were statistically significant and sufficiently high to demonstrate that the indicators and their underlying constructs were acceptable. In this study, extraction method principal axis factoring with Promax was used. The reliabilities and variance extracted for each latent variable revealed that the measurement model was reliable and valid. The result of Kaiser-meyer-olkin measure of sampling adequacy $=0.877$. Extraction sums of squared loadings $=50,163 \%$, Bartlett's test of sphericity Sig $=0.000$. The results of the factor analysis showed that the dimensions proposed for each construct had been demonstrated as acceptable. The result showed that only CE3 measurement item was not acceptable because factor loading was less than 0.5 . The factor loadings of 34 measurement items of 8 constructs ranging from 0.508 to 
0.848 , were greater than the conventional value of 0.50 and were acceptable (Hair et al., 2006) (Table 1).

\subsubsection{Confirmative Factor Analysis}

The results of confirmative factor analysis (CFA) showed an acceptable fit of the data $\left(X^{2}=1048.573\right.$, df $=495, p=$ $0.000, x^{2} / \mathrm{df}=2.123, \mathrm{GFI}=0.900, \mathrm{TLI}=0.915, \mathrm{CFI}=0.925$, RMSEA $=0.044$ ) (Figure 2). All factors loading were highly 0.5 significant on the expected constructs (Steenkamp \& Geyskens, 2006). Together, these demonstrated adequate convergent validity of the measures. Composite reliable and variance extracted was calculated on the basis of standardized weights estimated in the CFA model. Before the hypotheses test, the constructs of the questionnaire were tested for two psychometric properties: reliability and validity.

Table 1. Pattern matrix - EFA

\begin{tabular}{|c|c|c|c|c|c|c|c|c|}
\hline & \multicolumn{7}{|c|}{ Factor } \\
\hline & $\mathbf{1}$ & $\mathbf{2}$ & $\mathbf{3}$ & $\mathbf{4}$ & $\mathbf{5}$ & $\mathbf{6}$ & $\mathbf{7}$ & $\mathbf{8}$ \\
\hline SN2 & .848 & & & & & & & \\
\hline SN1 & .799 & & & & & & & \\
\hline SN4 & .749 & & & & & & & \\
\hline SN3 & .672 & & & & & & & \\
\hline SN5 & .557 & & & & & & & \\
\hline AT3 & & .774 & & & & & & \\
\hline AT2 & & .749 & & & & & & \\
\hline AT4 & & .668 & & & & & & \\
\hline AT5 & & .646 & & & & & & \\
\hline AT1 & & .621 & & & & & & \\
\hline SM2 & & & .772 & & & & & \\
\hline SM1 & & & .730 & & & & & \\
\hline SM3 & & & .681 & & & & & \\
\hline SM4 & & & .659 & & & & & \\
\hline SM5 & & & .520 & & & & & \\
\hline IB3 & & & & .841 & & & & \\
\hline IB4 & & & & .788 & & & & \\
\hline IB2 & & & & .681 & & & & \\
\hline IB1 & & & & .574 & & & & \\
\hline PD4 & & & & & .683 & & & \\
\hline PD3 & & & & & .676 & & & \\
\hline PD5 & & & & & .664 & & & \\
\hline PD1 & & & & & .653 & & & \\
\hline PD2 & & & & & .620 & & & \\
\hline HA2 & & & & & & .801 & & \\
\hline HA3 & & & & & & .702 & & \\
\hline HA1 & & & & & & .647 & & \\
\hline HA4 & & & & & & .508 & & \\
\hline TR2 & & & & & & & .744 & \\
\hline TR3 & & & & & & & .677 & \\
\hline TR1 & & & & & & & .600 & \\
\hline CE2 & & & & & & & & .803 \\
\hline CE1 & & & & & & & & .612 \\
\hline CE5 & & & & & & & & .602 \\
\hline
\end{tabular}

According to Bagozzi and Kimmel (1995), a factor displayed its reliability if its composite reliability was $>0.6$. The Cronbach's alphas of all constructs in this study were from 0.703 to 0.845 and the composite reliability of all constructs were 0.711 to 0.845 (Table 2). Thus, reliabilities and variance extracted for each latent variable revealed that the measurement model was reliable and valid. Measurement item achieved convergence validity if standardized regression weighted $>0.5$ and significant $p$ value $<0.05$ (Anderson \& Gerbring, 1988).

The results of this study showed that all standardized regression weights of 34 measurement items were from 0.509 to 0.861 , bigger than 0.5 , therefore they were convergent validity. This model of measurement items was consistent with market data, and there was no correlation between the measurement error should it achieved unidimensional. The correlation coefficient between constructs with others had to be $<0.9$ or $p$-value had to be $<$ 0.05 the new gain discriminant validity. All correlation coefficient between constructs with other construct were < 0.9 and all $p$-value were $<0.05$ so that the correlation coefficient of each pair of concepts were different from 1 at 95\% confidence level (correlation coefficient which you could infer that it followed $<1$ ) therefore, the constructs were discriminant validity.

The results showed the values of composite reliable and variance extracted of variables were greater than 0.5 (Hair, 2000) Therefore, this variable had satisfactory reliability and variance extracted aggregate. Cronbach's coefficient alpha reliability of the variables that had values greater than 0.6 scales should also meet the requirements of reliability coefficients. The correlation coefficient results showed that $\mathrm{P}$-value $=0.000$ of each pair of variable different from the one at the $95 \%$ confidence level, the correlation coefficients were less than 1 . Therefore, the variables gained valuable distinction.

Table 2. Reliability constructs

\begin{tabular}{|c|c|c|c|c|c|}
\hline Construct & $\begin{array}{c}\text { Cronbach's } \\
\text { Alpha }\end{array}$ & $\begin{array}{c}\text { Composite } \\
\text { Reliability }\end{array}$ & $\begin{array}{c}\text { Average } \\
\text { variance } \\
\text { extracted }\end{array}$ & $\begin{array}{c}\text { Convergent } \\
\text { validity }\end{array}$ & $\begin{array}{c}\text { Discriminant } \\
\text { validity }\end{array}$ \\
\hline SN & 0.845 & 0.845 & 0.529 & Accepted & Accepted \\
\hline SM & 0.802 & 0.789 & 0.429 & Accepted & Accepted \\
\hline HA & 0.767 & 0.773 & 0.464 & Accepted & Accepted \\
\hline CE & 0.703 & 0.710 & 0.454 & Accepted & Accepted \\
\hline TR & 0.715 & 0.711 & 0.451 & Accepted & Accepted \\
\hline AT & 0.816 & 0.821 & 0.481 & Accepted & Accepted \\
\hline IB & 0.811 & 0.823 & 0.524 & Accepted & Accepted \\
\hline PD & 0.791 & 0.776 & 0.415 & Accepted & Accepted \\
\hline
\end{tabular}




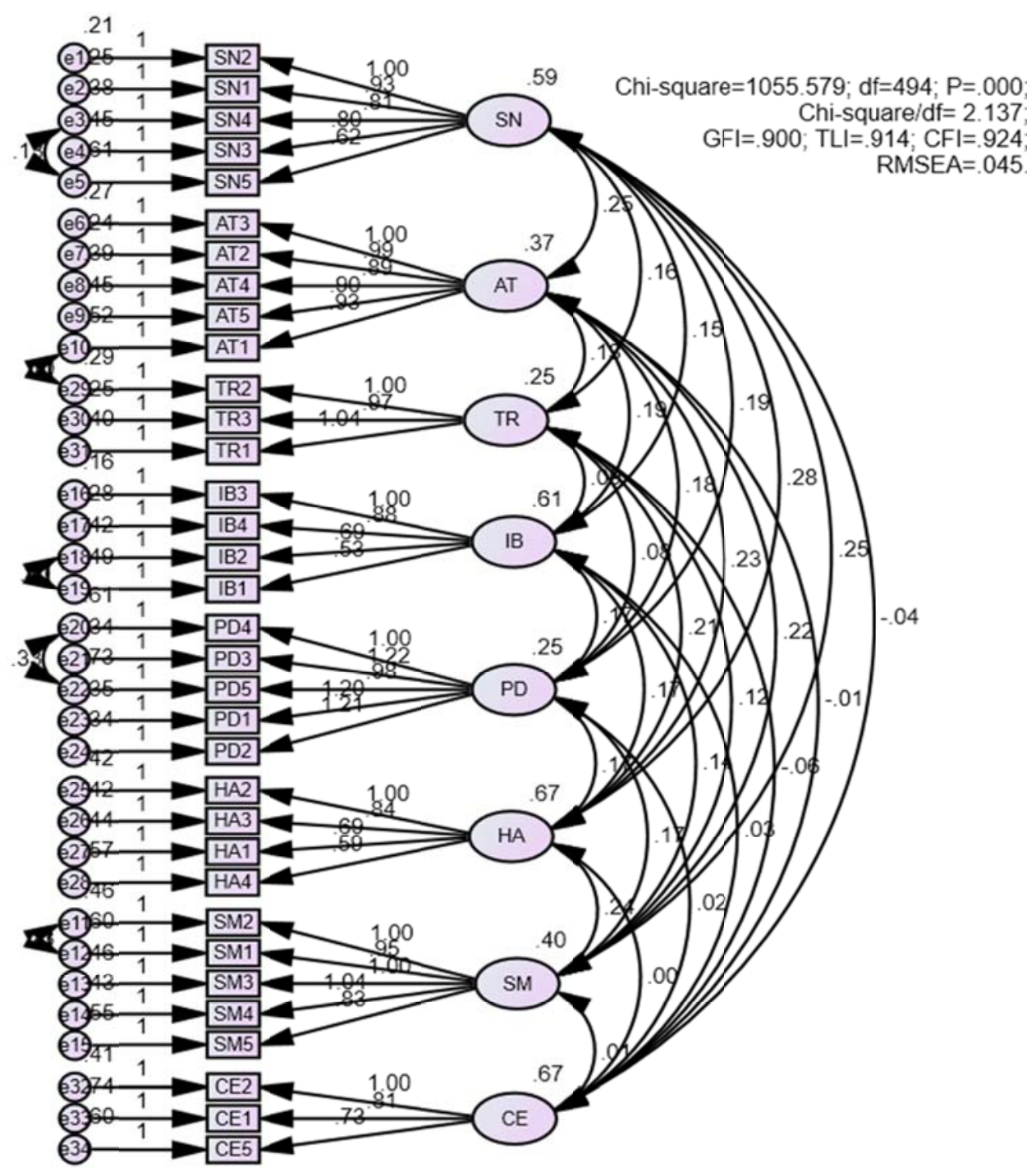

Figure 2. Confirmative factor analysis overall model

\subsubsection{Structural Equation Model}

This study's objective was to identify the relationships between hallyu 4.0, social media, consumer ethnocentrism, subjective norms, as well as trust, attitude, buying intention and purchase decision. To achieve this objective, the SEM was employed to test the interrelationships among all the research constructs, and to compare the modelled relationships with the observed scores. The structural equation model proposed is shown in (Figure 3).

The likelihood ratio chi-square test assessed the overall model fit. Chi-square was significant in this case (Chisquare $=1151.977 ; d f=510 ; p=0.00)$. Chi-square $/ d f=2.259$, satisfying the recommend $<3$ criterion for a good fit. Other indices of model fit included all exceed the recommended threshold level of 0.9 , except GFI (TLI= 0.907; CFI= 0.916; $I F I=0.916$; $G F I=0.892$ ). The root mean square error of approximation (RMSEA) described the discrepancy between the proposed model and the population covariance matrix. RMSEA was 0.046 , below the recommend $<0.08$ level (McKnight, Choudhury, \& Kacmar, 2002; Gefen, Straub, \& Boudreau, 2000). Thus, the overall model had a good fit. Therefore, we could proceed to examine the path coefficients of the structural model.

Results are presented in table 4 , all the parameters in the SEM model for the P-value were less than 0.05 so the relationships were significant in the model. All of the construct were positively correlated except consumer ethnocentrism was negatively correlated to trust with -0.136 standardized regression weight (Table 3). 


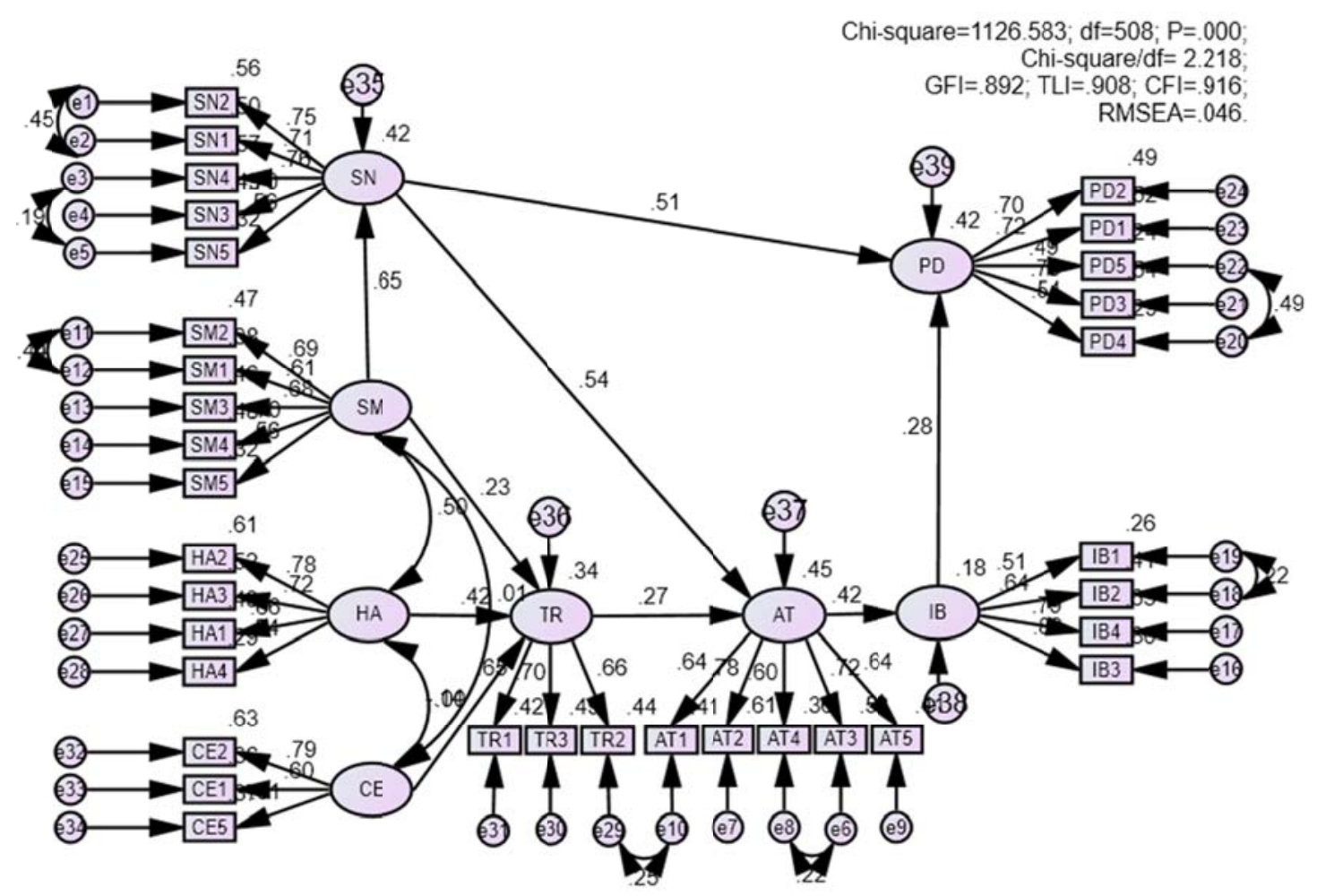

Figure 3. Structural equation model analysis

Table 3. Regression weights

\begin{tabular}{|c|c|c|c|c|c|c|c|}
\hline \multicolumn{2}{|c|}{} & \multirow{2}{*}{$\begin{array}{c}\text { Standardized regression } \\
\text { weights }\end{array}$} & \multicolumn{4}{|c|}{ Unstandardized regression weights } \\
\cline { 5 - 8 } & & Estimate & S.E. & \multicolumn{2}{c|}{ C.R. } & P \\
\hline TR & $<---$ & HA & .425 & .253 & .040 & 6.302 & ${ }^{* * *}$ \\
\hline SN & $<---$ & SM & .646 & .682 & .063 & 10.767 & ${ }^{* * *}$ \\
\hline TR & $<---$ & SM & .224 & .171 & .049 & 3.511 & ${ }^{* * *}$ \\
\hline TR & $<---$ & CE & -.136 & -.080 & .031 & -2.587 & .010 \\
\hline AT & $<---$ & TR & .271 & .321 & .060 & 5.338 & ${ }^{* * *}$ \\
\hline AT & $<---$ & SN & .543 & .466 & .047 & 9.889 & ${ }^{* * *}$ \\
\hline IB & $<---$ & AT & .421 & .571 & .068 & 8.405 & ${ }^{* * *}$ \\
\hline PD & $<---$ & SN & .515 & .382 & .046 & 8.258 & ${ }^{* * *}$ \\
\hline PD & $<---$ & IB & .280 & .178 & .032 & 5.613 & ${ }^{* *}$ \\
\hline
\end{tabular}

\subsubsection{Bootstrap Estimate Model}

Usually in the quantitative research, so as to test the reliability of the estimates, researchers have to divide the two samples. The first half is used for estimating the model parameters and the other half is for retesting. The other way is to repeat the study using a different sample. The Bootstrap method was suitable to replace (Schumacker \& Lomax, 2010). Bootstrap is a repeated sampling methods have replaced the original model in which, as the population. This study used bootstrap methods (Schumacker \& Lomax, 2010) with the number of repeated samples $N=1000$ to estimate the model in practice. The CR (bias/SE-bias) absolute value was less than 2.0. Thus, we could conclude that the estimates in the models can be trusted and fit.

\subsubsection{Model Fitting and Hypotheses Testing}

The final model fit statistics indicated that the overall variables were supported. All the hypotheses paths were significant, with significant at less than the $p<0.01$ level except H5. Overall, all the path coefficient-related hypotheses were supported from 0.226 to 0.446 . Consumer ethnocentrism influenced trust with the path coefficient- 


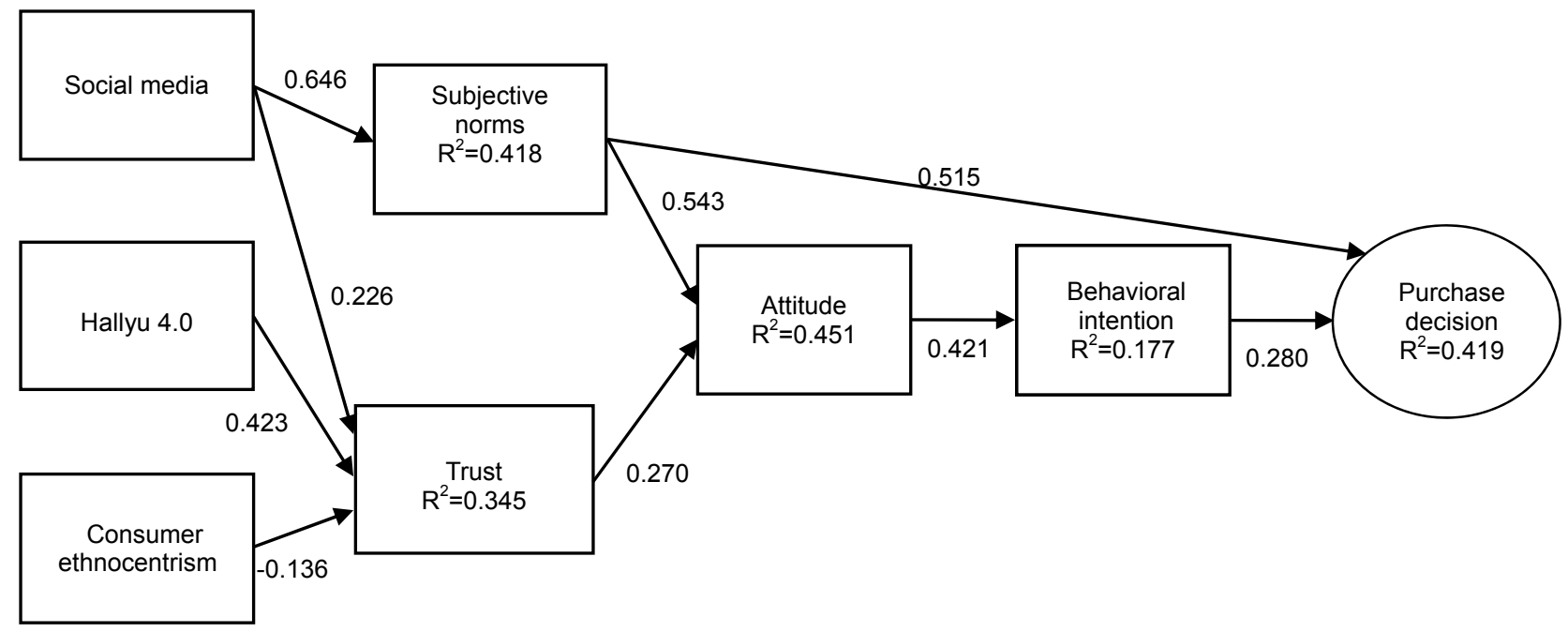

Figure 4. Final model

Table 4. Summary of hypotheses testing

\begin{tabular}{|l|l|c|}
\hline \multicolumn{1}{|c|}{ Hypotheses } & Results of testing \\
\hline H1 & Social media positively affects subjective norms. & Supported \\
\hline H2 & Social media positively affects trust. & Supported \\
\hline H3 & Hallyu 4.0 positively affects trust. & Supported \\
\hline H4 & Consumer ethnocentrism negatively affects trust. & Supported \\
\hline H5 & Consumer ethnocentrism positively affects purchase decision. & Rejected \\
\hline H6 & Subjective norms positively affect attitude toward behavior. & Supported \\
\hline H7 & Subjective norms positively affect purchase decision. & Supported \\
\hline H8 & Trust positively affects attitude toward behavior. & Supported \\
\hline H9 & Attitude toward behavior positively affects behavioral intention. & Supported \\
\hline H10 & Behavioral intention positively affects purchase decision. & Supported \\
\hline
\end{tabular}

related of -0.136 . The purchase decision was explained by $41.9 \%\left(R^{2}=0.419\right)$. An important result showed that hallyu 4.0 strongly impacted trust with the path coefficient-related $=$ 0.423. Social media influenced not only trust but also subjective norms with the path coefficient-related $=0.646$.

\section{Conclusions and Research Limitations}

The theoretical contribution of this study was to identify the impact of hallyu 4.0, social media, and consumer ethnocentrism on Korean products purchase decision of generation $\mathrm{C}$ in Vietnam. Based on the SEM model and final model described in this study, there are some primary conclusions: The hallyu 4.0, social media, and consumer ethnocentrism are independent variables. They impact purchase decision through mediating variables such as trust, subjective norms, attitude and behavioral intention. This study has shown that social media influences not only to trust but also to subjective norms. Subjective norms not only influence attitude but also have a directly impact on purchase decision. Subjective norms influence stronger than behavioral intention. Consumer ethnocentrism influence negatively on trust. This study also discovers an interesting fact that trust and attitude variables have an impact on behavioral intention and purchase decision.

In spite of the limitations, the findings provide tentative conclusions which may stimulate future research. Based on the findings of the study, several additional studies could be developed. Firstly, in this study, the amount of sample is 575 respondents although satisfying requirements for research, but may not be large for multiple group analysis, such as effects of Southern, Central and Northern of Vietnam. The limitations of this research would be an interesting topic for future research. Secondly, future research could also seek to determine whether the effectiveness of hallyu 4.0 and social media varies based on the industry of the sender, i.e. convenience product; fast moving consumer goods or hi-tech products, etc. 


\section{References}

Ahtola, O. T. (1975). Toward a Vector Model of Intentions, in B. B. Anderson (Ed.) Advances in Consumer Research, Cincinnati: The Association for Consumer Research, III, 469-476.

Ajzen, I., \& Fishbein, M. (1975). A Bayesian analysis of attribution processes. Psychological Bulletin. 82(2), 261-277.

Ajzen, I., \& Fishbein, M. (1980). Understanding Attitudes and Predicting Social Behavior. Englewood Cliffs, New York: Prentice-Hall.

Ajzen, I. (1991). The theory of planned behavior. Organizational Behavior and Human Decision Processes, 50, 179-211.

Ajzen, I. (2006). Constructing a TPB Questionnaire: Conceptual and Methodological Considerations. Retrieved May 27, 2018 from http://www.people.umass.edu/aizen/pdf/tpb.measure ment.pdf.

Akhter, S. H. (2010). Service attribute satisfaction and actual repurchase behavior: the mediating influence of overall satisfaction and purchase intention. Journal of Consumer Satisfaction, Dissatisfaction \& Complaining Behavior, 23, 52-64.

Anderson, J. C., \& Gerbing, D. W. (1988). Structural Equation Modeling in Practice: A Review and Recommended Two-Step Approach. Psychological Bulletin, 103(3), 411-423.

Bagozzi, R. P., \& Kimmel, S. K. (1995). A comparison of leading theories for the prediction of goal-directed behaviours. British Journal of Social Psychology, 34, 437-461.

Balabanis G., \& Diamantopoulos, A. (2004). Domestic Country Bias, Country-of-Origin Effects, and Consumer Ethnocentrism: A Multidimensional Unfolding Approach, Academy of Marketing Science Journal, 32(1), 80-95.

Baughn, C. C., \& Yaprak, A. (1996). Economic nationalism: Conceptual and empirical development. Political Psychology, 17(4), 759-778.

Bazzarvoice. (2012a). Power of Word Of Mouth. Social Commerce Statistics. Retrieved May 3, 2013 from http://www.bazaarvoice.com/research-and-insight/ social-commerce-statistics/\#Word of mouth

Bazzarvoice. (2012b). Social Trends Report 2012. Social commerce statistics. Retrieved May 10, 2013 from http://www.bazaarvoice.com/research-and-insight/ social-commerce-statistics/\#Trust

Booz \& Company. (2010). The rise of Generation C. Implications for the world of 2020. Strategy \& Formerly Booz \& Company, 1-15.
Brady, M. K., \& Robertson, C. J. (2001). Searching for a consensus on the antecedent role of service quality and satisfaction: an exploratory cross-national study. Journal of Business Research, 51(1), 53-60.

Cho, D. Y., Kwon, H. J., \& Lee, H. Y. (2007). Analysis of trust in internet and mobile commerce adoption. Proceedings of the 40th Hawaii International Conference on System Science, IEEE Computer Society, Washington, DC, USA, January 03 - 06, 2007. Doi:10.1109/HICSS.2007.76

Coyne, I. T. (1997). Sampling in qualitative research. Purposeful and theoretical sampling; merging or clear boundaries. Journal of Advanced Nursing, 26, 623-630.

Cruz, B., \& Mendelsohn, J. (2010). Why Social Media Matters to your Business. Chadwick Martin Bailey Research Report. Retrieved April 20, 2018 from http://www.cmbinfo.com/cmb-cms/wp-content/ploads /010/04/Why_Social_Media Matters_2010.pdf.

Davies, J., Foxall, G. R., \& Pallister, J. (2002). Beyond the intention-behavior mythology: An integrated model of recycling. Marketing Theory, 2(1), 29-113.

Featherman, M., \& Pavlou P. (2002). Predicting e-services adoption: A perceived risk facets perspective. In Proceedings of the Eighth Americas Conference on Information Systems. Dallas, TX, USA, August 9-11, 2002.

Fishbein, M., \& Ajzen, I. (1975). Belief, Attitude, Intention, and Behavior: An Introduction to the Theory and Research. Reading, MA: Addison-Wesley.

Fishbein, M., \& Ajzen, I. (2010). Predicting and changing behavior: The reasoned action approach. New York: Taylor \& Francis.

Foux, G. (2006). Consumer-generated media: Get your customers involved. Brand Strategy, 8, 38-39.

Gefen, D., Straub, D. W., \& Boudreau, M. C. (2000). Structural equation modeling and regression: guidelines for research practice, Communications of the AIS, 4(7), 1-78.

Gefen, D. (2002). Reflections on the dimensions of trust and trust worthiness among online consumers. ACM SIGMIS Database, 33(3), 38-53.

Gefen D., Karahanna E., \& Straub D. W. (2003). Trust and TAM in online shopping: an integrated model, MIS Quarterly, 27(1), 51-90.

Griffin, M. A., Neal. A., \& Parker, S. K. (2007). A new model of work role performance: Positive behavior in uncertain and interdependent contexts. Academy of Management Journal, 50(2), 327-347.

Hair, J. F., Bush, R. P., \& Artinau, D. J. (2000). Marketing research: A practical approach for the new millennium. Boston, MA: Irwin/McGraw-Hill. 
Hair, J., Aderson, R., Tatham, P., \& Black, W. (2006). Multivariate Data Analysis, 6th ed., Upper Saddle River, NJ: Prentice-Hall.

Harrison, M. D., Vivek, C., \& Charles, K. (2002). The impact of initial consumer trust on intentions to transact with a web site: A trust building model. Journal of Strategic Information Systems, 11(2002), 297-323.

Herche, J. (1992). A note on the predictive validity of the CETSCALE. Journal of the Academy of Marketing Science, 20(3), 261-264.

Hogarth, H. K. (2013). The Korean Wave: An Asian Reaction to Western-dominated Globalization, Perspectives on Global Development and Technology, 12, 135-151.

Internetworldstats. (2018). Internet Users, Facebook Subscribers \& Population Statistics

for 35 countries and regions in Asia. Internet Usage in Asia. Retrieved May 20, 2018 from https://.com/stats.htm.

Jackson, C., Chow, S., \& Leitch, R. (1997). Toward an understanding of the behavioral intention to use an information system. Decision Sciences, 28, 357-389.

Kim, J., \& Park, K. S. (2004). The Analysis of the Effects of Haliu Phenomenon on the Chinese Young Generation's Fashion Style. Journal of the Korean Society of Clothing and Textiles. 28(1), 154-164.

Kim, B. R. (2015). Past, Present and Future of Hallyu (Korean Wave). American International Journal of Contemporary Research, 5(5), 154-160.

Lee, O. (2007). Does the Korean Wave Bring About Country-of-origin Effect?. Journal of Korea Trade, 32(5), 405-426.

Lee, S. J. (2011). The Korean Wave : The Seoul of Asia. The Elon Journal of Undergraduate Research in Communications, 2(1), 5-93. Retrieved from http://www.elon.edu/docs/e-web/academics/ ommunications/research/vol2no1/09SueJin.pdf.

Lee, W. J. (2015). Korean Stars on the TV Drama and Their Influence to Foreign Fan's Behavior, Advanced Science and Technology Letters, 102, 79-82.

Loudon, D. L., \& Della Bitta, A. J. (1993). Consumer behavior: Concepts and applications. 4th ed. New York: McGraw-Hill.

Mangold, W. G., \& Faulds, D. J. (2009). Social media: The new hybrid element of the promotion mix. Business Horizons, 52, 357-365.

Mathur, P., Black, J. E., Cao, J., Berger, P. D., \& Weinberg, B. D. (2012). The Impact of Social Media Usage on Consumer Buying Behavior. Advances in Management, 5(1), 14-22.

Mayer, R.. C., Davis, J. H., \& Schoorman, F. C. (1995). An integrative model of organizational trust. The Academy of Management Review, 20(3), 709-734.
McKnight, D. H., Choudhury, V., \& Kacmar, C. (2002). Developing and validating trust measures for ecommerce: an integrative typology, Information Systems Research, 13(3), 334-359.

Nguyen T. D., Nguyen T. T. M., \& Barret. N. J. (2008). Consumer ethnocentrism, cultural sensitivity and intention to purchase local products - evidence from Vietnam, Journal of Consumer Behavior, 7, 88-100.

Nguyen, X. T. (2015). The impact of social media usage on hi-tech products purchase decision of generation $Y$ in Vietnam. GE-International Journal of Management Research. 3(10), 123-147.

Nielsen. (2009). Global Advertising Consumers Trust Real Friends and Virtual Strangers the Most, Nielsen Wire, 1 July. Retrieved May 15, 2017 from http://www.nielsen.com/us/en/newswire/2009/globaladvertising-consumers-trust-real-friends-and-virtualstrangers-the-most.html.

Nielsen. (2012). State of the media - the social media report 2012. Retrieved on May 25, 2018 from: http://www.nielsen.com/us/en/insights/reports/2012/st ate-of-the-media-the-social-media-report-2012.html.

Nunnally, J. C. (1978). Psychometric theory (2nd ed.). New York, NY: McGraw-Hill.

Nunnally, J. C., \& Bernstein, I. H. (1994). Psychometric theory (3rd ed.). New York, NY: McGraw-Hill.

Pang, C., \& Hwang, U. (2007). The Korean Wave and Cultural Communication, Seoul, Korea: Communication Books.

Pickett, P. (2017). Learn the Characteristics of Generation C. Retrieved May 10, 2018 from https://www.thebalancecareers.com/who-isgeneration-c-and-what-are-they-all-about-2071937.

Peterson, R. A. (1994). A meta-analysis of Cronbach's coefficient alpha. Journal of Consumer Research, 21, 381-391.

Pitta, D. A., \& Fowler, D. (2005). Online consumer communities. Journal of Product \& Brand Management, 14(5), 283-291.

Ranjbairan, B., Barari, M., \& Zabihzade, K. (2011). Ethnocentrism among Iranian Consumer with different consumption habits, International Journal of Marketing Studies, 3(3), 30-41.

Rousseau, D. M., Sim, B. B., Ronald, S. B., \& Colin, C. (1998). Not so different after all: A cross discipline view of trust. Academy of Management Review, 23(3), 393-404.

Sanchez, F. R., Iniesta, B. M. A., Schlesinger, D. W., \& Rivera, R. P. (2010). Analysis of the value creation in higher institutions: A relational perspective. Theoretical and Applied Economics, 17(10), 25-36.

Schumacker, R. E., \& Lomax, R. G. (2010). A beginner's 
guide to structural equation modeling, 3rd ed. New York, NY: Routledge.

Sheppard, B. H., Hartwick, J., \& Warshaw, P. R. (1988). The theory of reasoned action: A meta-analysis of past research with recommendations for modifications and future research. Journal of Consumer Research. 15, 325-343.

Shimp, T. A., \& Sharma, S. (1987). Consumer Ethnocentrism: Construction and Validation of the CETSCALE, Journal of Marketing Research, 24, 280-289.

Shin, D. (2010). The effects of trust, security and privacy in social networking: a security-based approach to understand the pattern of adoption. Interacting with Computers, 22(5), 428-38.

Shoham, A., \& Brencic, M. M. (2003). Consumer ethnocentrism, attitudes and purchase behaviour: A Israeli Study, Journal of International Consumer Marketing, 15(4), 67-86.

Slater, S. (1995). Issues in Conducting Marketing Strategy Research. Journal of Strategic Marketing, 3(4), 257270.

Smiciklas, M. (2011). Word of Mouth Marketing. Social Media Explorer. [Electronic version]. Retrieved April 25, 2018 from: http://www.socialmediaexplorer.com/ ocial-media-marketing/word-of-mouth-marketing.

Sommer, L. (2011). The theory of planned behavior and the impact of past behavior. International Business \&
Economics Research Journal, 10(1), 91-110.

Statista. (2018). Leading countries based on number of Facebook users as of April 2018 (in millions). Retrieved May, 25, 2018 from https://www.statista.com/tatistics/268136/top-15countries-based-on-number-of-facebook-users/.

Steenkamp, J. B. E. M., \& Geyskens, I. (2006). How Country Characteristics Affect the Perceived Value of a Website. Journal of Marketing, 70, 136-150.

Sumner, W. G. (1906). Folkways. Boston, MA: Ginn.

Yoon, S. J. (2002). The antecedents and consequences of trust in online-purchase decision. Journal of Interactive Marketing, 16(2), 47-63.

Yu, H., Kim, C., \& Kim, H. (2012). Investigating Cosmetic Purchase of International Tourists in South Korea. International Journal of Management Cases, 14(1), 398-410.

Yurdugul, H. (2008). Minimum sample size for Cronbach's coefficient alpha: Monte-Carlo study. H. U. Journal of Education, 35, 397-405.

Zeithaml, V. A., Berry, L. L., \& Parasuraman, A. (1996). The Behavioral consequences of service quality. Journal of Marketing, 60(2), 31-46.

Zeng, F., Hu, Z., Chen, R., \& Yang, Z. (2009). Determinants of online service satisfaction and their impacts on behavioral intentions. Total Quality Management, 20(9), 953-969. 